\title{
CURRENT STATE OF STUDY AND USE OF MATERIALS OF THE ORENBURG EXPEDITION IN HISTORIOGRAPHY
}

\author{
Saparniyazov A. \\ Junior researcher of the department History, Karakalpak research Institute of Humanities, \\ Karakalpak branch of the Academy of Sciences Republic of Uzbekistan, \\ Nukus, Uzbekistan.
}

Article DOI: https://doi.org/10.36713/epra4777

\begin{abstract}
The purpose of the research is to analyze the works of researchers on the problem of socio-economic and political history of the Karakalpaks, their relations with Russia in the XVIII century, written mainly on the basis of documents of the Orenburg expedition. The nature and main directions of studying the issue under consideration are defined. The available literature is shown, which is diverse in genre and level of theoretical generalization, as well as in the range of issues raised in them. Scientific novelty consists in a critical consideration of the issue with the involvement of the works of modern scientific historians. As a result, it is found that not all aspects of the history of the Orenburg expedition in the study of the Karakalpaks of the XVIII century are fully developed today. In this regard, the need to continue the in-depth study and development of issues related to the history of the Karakalpaks of the XVIII century is justified.
\end{abstract}

KEYWORDS: Russian Empire, Central Asia, karakalpaks of the XVIII century, materials of the Orenburg expedition, traveler's reports, Russian archives, historiographical research.

\section{INTRODUCTION}

The materials of the Orenburg expedition of 1734-1744 contain the earliest Russian-language information about the Karakalpaks, so any historical and ethnological research, one way or another, begins with this source. We think that on the basis of valuable information extracted from the documents of the Orenburg expedition, it is possible to recreate a more complete picture of the life of the Karakalpak people of the XVIII century.

The study of the history of the Karakalpaks of the XVIII century based on the documents of the Orenburg expedition contains considerable difficulties. Writing the socio-economic and political events of the period under study is allowed to be relatively easy work, since they are reflected in the documents of the Orenburg expedition. However, understanding them without specifying the main reasons for these events is not an easy task. And we believe that the reconstruction of the socio-economic and political history of the Karakalpaks of the XVIII century is still far from being completed.

The degree of study of the materials of the Orenburg expedition is varied. Some of them were discovered long ago and studied well enough, they were widely used in scientific research, and others are still being introduced into scientific circulation.

Since the beginning of the 90 s of the XX century, new, significantly expanded and revised publications have appeared in our country, which summarize the results of many historical studies, including on the problem that interests us. These works contain a lot of interesting material that contributes to the correct, that is, unbiased and objective coverage of our chosen topic.

\section{LITERATURE REVIEW}

In 1993, Professor M. Tileumuratov wrote the work "Historical cultural relations of the Karakalpaks with Russia and Bashkiria in the XVIIIearly XX centuries" [7]. The task assigned to the 


\section{SJIF Impact Factor: 7.001| ISI I.F.Value:1.241| Journal DOI: 10.36713/epra2016 ISSN: 2455-7838(Online) EPRA International Journal of Research and Development (IJRD)}

author of this study was to summarize the results of specific research on the history of culture of Karakalpakstan, to study the Karakalpak culture in interaction with the Russian and Bashkir peoples in the XVIII-XIX centuries. When writing this book, he was particularly interested in the works of such participants of the Orenburg expedition as V. Tatishchev, I. Kirilov, P. Rychkov and other Russian researchers.

\section{DISCUSSION}

Among the Karakalpak researchers of this period, we can note O. Yusupov, whose activity was associated with the study of the history of the Karakalpaks based on the materials of the Orenburg expedition. Among his works of great interest is "Janibek Batyr, Maman Batyr, Murad Sheikh, Aziz Baba, Korazbek Biy-atalyk, Khojamurat Biy and Toremurat Biy Sufis or sources from the past "Maily shengel" [10] (this book is written in the Karakalpak language). In this work, based on rich archival materials, many aspects of the history of the Karakalpaks and aralans who lived in the Aral sea, the Syr Darya and the lower reaches of the Amu Darya are analyzed. Events related to the trips of the first and last Karakalpak ambassadors Janibek Batyr and Maman Batyr to Moscow and St. Petersburg are covered. Data are available about the relationship of the ruler Aral possession of Karateka and Russian General I.Tevkelev.

In 1995, a dissertation was written by and.Piskunova on the topic "Syrdarya Karakalpaks and Russia in the XVIII century" [5]. This work is devoted to the study of problems, trends, and features of relations between the Syrdarya Karakalpaks and the peoples of the Russian Empire in the XVIII century. In the relevant parts of this dissertation, we used some information from the materials of the Orenburg expedition, which served as one of the source bases of the research.

The work of academician S. Kamalov "From the history of the formation of the Karakalpak people and its statehood" [4] (this book is written in the Karakalpak language) is still the most relevant today. In this small volume of work, S. Kamalov, using some data from the materials of the Orenburg expedition, was able to reveal in a popular form questions about the origins and stages of the formation of the Karakalpak state over many centuries.

Questions of the Aral-Kungrad domain are considered in the work of G. Khozhaniyazov [8]. In it, the author tried to carry out a fairly detailed analysis of the history of the Aral domain, highlighting the geographical, socio-political and demographic situation of this state Association.

In 2018, scientific historians of the Karakalpak research Institute of Humanities of the
Karakalpak branch of the Academy of Sciences of the Republic of Uzbekistan G. Khozhaniyazov and A. Dzhumashev published a scientific article entitled "the Ethnic composition of the Aral-Kungrad domain in the XVII-XIX centuries: a forgotten page of history" [9]. The reviewed article was directly devoted to the history of the Aral domain. The authors skilfully presented the content of the work on the basis of Eastern (Abulgazi, Munis, Agakhi) and Russian information (D. Gladyshev, I. Muravin, P. Rychkov). The structure of this article allows the reader to gain a systematic understanding of the history of the population, territories, as well as toponymic names, which explains in detail the etymological origin of the name of the Aral sea.

Among the Uzbek historians, the question we are studying was touched upon by H.Gulomov [1]. In his monographic work, he considered the patterns and directions of development of interstate relations between the Central Asian khanates and Russia in the XVIII - first half of the XIX century, paying special attention to the roles of diplomatic missions in Bukhara, Khiva, Tashkent and Kokand.

From the above brief review, it can be seen that Karakalpak and Uzbek historians during the period of independence, the history of the Karakalpaks of the XVIII century was covered in the context of the Orenburg expedition. However, this historiographical analysis of scientific works allows us to conclude that the history of the Karakalpaks has not yet been fully studied on the basis of the documents of the Orenburg expedition and the military advance of Russia into the territory of the Karakalpaks of the XVIII century, which makes it possible to speak about the incomplete development of this problem. In addition, many of the materials available in various archives and libraries have not yet been fully introduced into scientific circulation and subjected to analysis and scientific generalization.

Some of the issues of our topic may be covered as a result of research of works and collections on the history of other peoples of Central Asia and Kazakhstan, who, like the Karakalpaks, experienced colonial oppression from the Russian tsardom. This is mainly the research of Kazakh historians, which highlights the situation of the peoples before and after the conquest of Central Asia and Kazakhstan by Russia.

The Asian region has always attracted the attention of Europeans. In the XVIII century, Central Asia was visited by many Western travelers, diplomats, traders and missionaries, who captured what they saw in their memoirs, travel notes and diaries. As a variety of information about the region accumulated, the cognitive interest in it grew. All this is described in a fascinating way In $\mathrm{K}$. 


\section{EPRA International Journal of Research and Development (IJRD)

Esmagambetov's book "What was written about us in the West" [3].

I. Erofeeva's monograph "Khan Abulkhair: commander, ruler and politician" [2] is devoted to the political biography of the military and statesman of the Kazakh people of the XVIII century - Khan Abulkhair. It examines the history of the Orenburg expedition on the basis of its own documents, along with some historical information about the Karakalpaks, as well as their role in the sociopolitical life of the peoples of Central Asia in the XVIII century.

The collective work "the Past of Kazakhstan in sources and materials" [6] provides large auxiliary materials for our research. This source is selected and systematized by chronological and thematic features excerpts from documents of travelers and diplomats of the XVIII century. The materials contained in these collections, along with the history of the Kazakhs, reflect the life, relationships of the Karakalpaks with neighboring States and peoples, as well as the history of the first decades of Russian colonial expansion to the East. These works include excerpts from the works of participants of the Orenburg expedition, which expose the predatory policy of tsarist Russia.

\section{CONCLUSION}

Thus, assessing the degree of study of the topic, we can state that a huge layer of historical material has been accumulated, which allows us to expand the range of scientific interests. However, the history of the Karakalpaks in the materials of the Orenburg expedition is not sufficiently studied. In addition, many documents of the Orenburg expedition have not yet been fully introduced into scientific circulation and analyzed.

\section{REFERENCES}

1. Gulomov H. Diplomatic relations of the States of Central Asia with Russia in the XVIII-first half of the XIX century. Tashkent: Fan, 2005.

2. Erofeeva I. Khan Abulkhair: commander, ruler and politician. Almaty: Sanat, 1999.

3. K. Esmagambetov. What was written about us in the West. Alma-Ata: Kazak Universiteti, 1992.

4. Kamalov S. From the history of the formation of the Karakalpak people and its statehood. Nukis: Ilim, 2001.

5. Piskunova I. Syrdarya Karakalpaks and Russia in the XVIII century. ... candidate of historical Sciences. Nukus: Institute of history, archeology and Ethnography of the Karakalpak branch of the Academy of Sciences of Uzbekistan, 1995.

6. The past of Kazakhstan in sources and materials / Under the editorship of Prof. Asfendiyarova S. D. and prof. Kunte P. A. 2nd ed. Sat. 1: (V century BC - XVII century ad). Almaty: Kazakhstan, 1997; the Past of Kazakhstan in sources and materials / Under the editorship of
Prof. Asfendiyarova S. D. 2nd ed. Sat. 2. Almaty: Kazakhstan, 1998.

7. Tileumuratov M. Historical and cultural ties of the Karakalpaks with Russia and Bashkiria in the XVIII-early XX centuries. Nukus: Bilim, 1993.

8. Khozhaniyazov City of Aral-Kungrad possession // Bulletin of the CMT Academy of Sciences of Uzbekistan. Nukus: 2004, no. 7. - SS. 52-55.

9. Khozhaniyazov G., Dzhumashev A. Ethnic composition of the Aral-Kungrad domain in the XVII-XIX centuries: a forgotten page of history // Oases of the silk road: modern problems of Ethnography, history and source studies of the peoples of Central Asia: to The 100th anniversary of doctor of historical Sciences Balkis Khalilovna Karmysheva, 2018: collection of scientific articles / ed. Kotyukova T. V. Moscow: 2018. - SS. 131-141.

10. Yusupov O. Dzhanibek Batyr, Maman Batyr, Murad Sheikh, Aziz Baba, Korazbek Biy-atalyk, Khojamurat Biy and Toremurat Biy Sufis or sources from the past "Maila shengel". Nukis: Karakalpakstan, 1993. 